O. Smirnov, O. Nakonechnyi, A. Bologov

Ivan Kozhedub Kharkiv National Air Force University, Kharkiv

\title{
FORMATION OF THE MEASURING CHANNEL OF MULTIFUNCTION PHASED ARRAY RADAR IN TRACKING MODE
}

In the article is considered the principle of the formation of the measuring channel for multifunction phased array radar in tracking mode using one of the short-range air defense radar system as an example. A new approach to the problem is offered, which is based on considering the change of noise levels both in the measuring channel and in the dynamic model of the target being tracked and is adaptive to its motion in space.

The number of simultaneously monitored targets is calculated under the condition of application of the proposed principle of channel formation. The efficiency of the obtained solutions is confirmed. The conclusion is made about the expediency of application of this method in the existing air defense systems, the modernization of which is currently underway.

Keywords: multifunction phased array radar, tracking mode, measuring channel, processing ability.

\section{Introduction}

Problem statement. The analysis of modern tasks facing short-range air defense systems encourages the search for new ways to increase the capacity of their radar stations (radars), in particular, in the mode of tracking small air targets.

The analysis of recent researches and publications. A wide range of tasks performed by multifunction phased array radar (MPAR) [1-5] creates a need for the use of various sets of probing signals for the implementation of each of its operating modes [6]. An example of such an MPAR is an aiming radar (AR) of the 9K330 air defense missile system (ADMS), which can employ two radar signals for tracking one target [7]:

- S2 (for the target range of 24 to $2 \mathrm{~km}$ );

- S3 (for the target range of up to $2 \mathrm{~km}$ ).

Purpose of the article is: the possibility assessment of increasing the capacity of the existing radar equipment through the application of a new approach to the formation of the measurement channel.

\section{Statement of basic materials}

Signal S2 of an aiming radar (AR) of the 9K330 air defense missile system is a train of 32 linearfrequency modulation (LFM) pulses with the duration of $9.1 \mu \mathrm{s}$, and signal $\mathrm{S} 3$ is a quasi-continuous sequence of 210 radio pulses with the duration of $0.92 \mu \mathrm{s}$.

It is necessary to specify some characteristics of these signals for the target moving radially towards the AR at a speed $V_{t}=700 \mathrm{~m} / \mathrm{s}$.

The repetition frequency $F_{S 2}$ of the signal $\mathrm{S} 2$ can be found from the condition of the unambiguity of measuring the target range $F_{S 2}[8]$ :

$$
F_{S 2}=\frac{c}{2 R K_{r}},
$$

where $\quad c=3 \cdot 10^{8} \mathrm{~m} / \mathrm{s}$ is the speed of light;

$K_{r}=1.25$ is the reserve coefficient.

When $c=24 \mathrm{~km}$, the required value is $F_{S 2}=$ $5 \mathrm{kHz}$. Therefore, the duration of the considered signal $T_{S 2}$ is defined [3]:

$$
T_{S 2}=\frac{N_{S 2}}{F_{S 2}}=6400 \mu s,
$$

where $N_{S 2}$ is the number of pulses in the pack.

Because the pulse wavelength of the considered radar is $\lambda=3 \mathrm{sm}$, then for the received speed of the tracked target similar parameters of signal S3 are equal to [9]:

$$
\begin{gathered}
F_{S 3}=\frac{2 V_{t}}{\lambda}=46.7 \mathrm{kHz}, \\
T_{S 3}=\frac{N_{S 3}}{F_{S 3}}=4500 \mu \mathrm{s},
\end{gathered}
$$

where $N_{S 3}$ is the number of pulses in the quasicontinuous sequence;

$$
V_{t} \text { - target speed. }
$$

The considered radar signals emitted in a certain order in the same angular direction make up the socalled "S2 $+\mathrm{S} 3$ procedure" (Fig. 1).

The analysis of Fig. 1 shows that the measuring channel of the MPAR in the tracking mode formed in a similar manner has the following main features: 


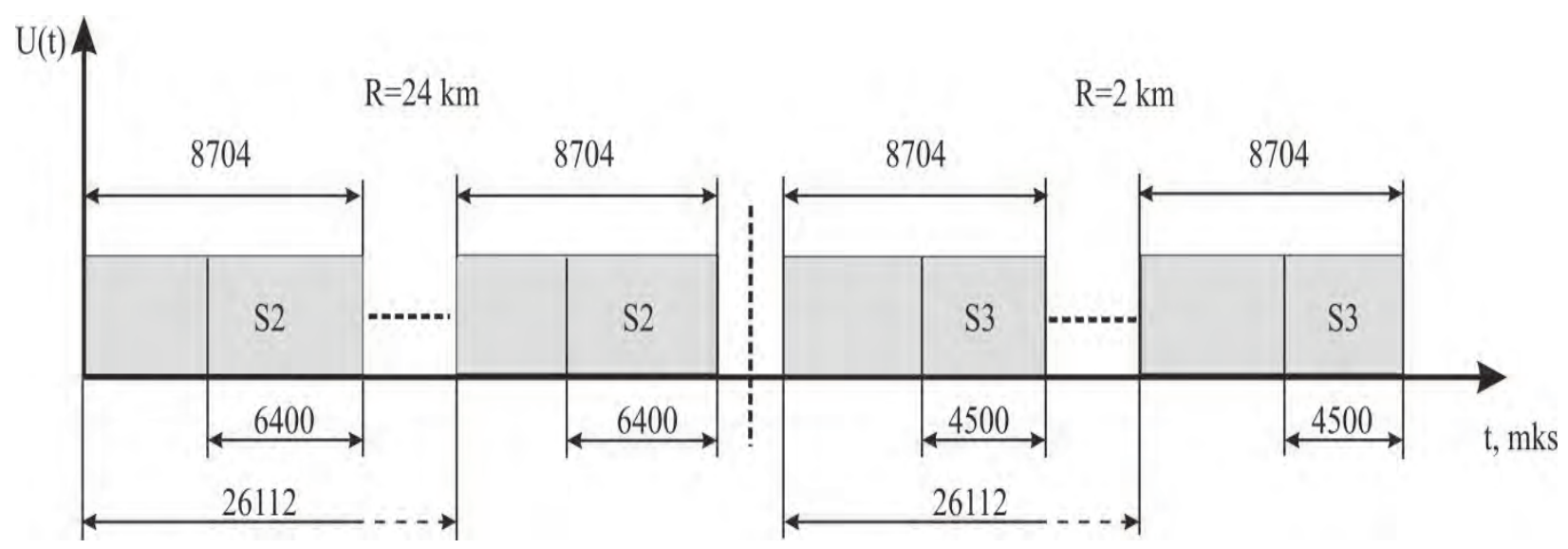

Fig. 1. S2 $+\mathrm{S} 3$ procedure

1) the time allocated for tracking the target is made up of measuring cycles of a fixed duration of $8704 \mu \mathrm{s}$, which are repeated with the frequency of $38.3 \mathrm{~Hz}$;

2) the portion of the cycle duration is used to form the measuring channel itself and is not directly involved in the measurement process, in other words, it corresponds to the loss of time.

Considering these features, we can evaluate the possibility of increasing the throughput capacity of the guidance station of 9K330 ADMS due to the refusal to track the target with constant values of the duration of measuring cycle and the repetition rate.

The general approach to solving the problem, which is based on taking into account the change of noise levels in the measuring channel of the radar and the dynamic model of the tracked target when it moves across the view area, has been offered in the work [10] and has been specified by providing the appropriate method in the article [11].

The main results of this method (after some transformations) are in calculating the duration of the measuring cycle $\tau$ and the frequency of its repetition $F_{\tau}$ by the following equations:

$$
\tau=A\left[\sqrt{1-4 \Sigma_{E A}^{3} \cdot \frac{G \tau_{0}}{A^{2}}}-1\right] \cdot\left(2 \Sigma_{E A} G\right)^{-1},
$$

$$
F_{\tau}=\frac{E}{\tau},
$$

where:

$$
\begin{gathered}
A=G H-\Sigma_{E A} G_{\tau_{0}}-E, \\
E=\left[\frac{\sqrt{\Sigma_{E A}^{3} \cdot G_{\tau_{0}}}+\sqrt{D / 4}}{\Sigma_{E A}^{2}}\right]^{2}, \\
D=2 \Sigma_{E A}^{3} \cdot G_{\tau_{0}}-4\left(\Sigma_{E A} G_{\tau_{0}}-G H\right) \Sigma_{E A}^{2} .
\end{gathered}
$$

The variables included in relations (1-5) have the following meaning:

$\Sigma_{E A}$ is the required evaluating accuracy of the tracked target coordinates;

$G$ is the noise intensity of the target dynamic model;

$\tau_{0}$ is the loss of time in the measuring cycle;

$H$ is the noise intensity in the measuring channel.

Let $\tau_{0}=500 \mu \mathrm{s}$ [7], and the rest of the target and radar parameters coincide with those adopted in the work [11]. Then relations (1-5) allow us to obtain the so-called modified S2A + S3A procedure (Fig. 2), where the letter " $A$ " means the radar signal adaptation to a change of noise levels in the radar measuring channel and in the dynamic model of the target during tracked it moves in the view area of the AR.

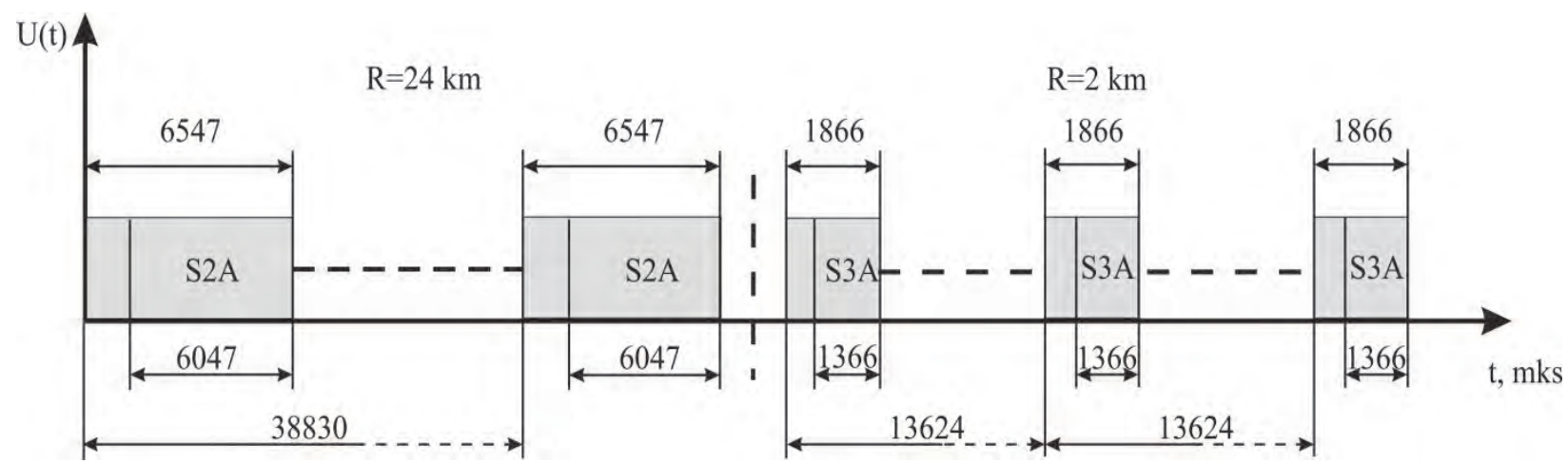

Fig. 2. S2A + S3A procedure 
The analysis of Fig. 2 shows that the repetition rate of the measuring cycles with a duration of $6547 \mu$ s and $1866 \mu$ s generated by the offered method is $25.8 \mathrm{~Hz}$ and $73.4 \mathrm{~Hz}$ (for signals S2A and S3A, accordingly). In this case, the number of simultaneously served targets in the tracking mode $N_{t}$ can be determined according to the work [12] as follows:

$$
N_{t}=\left(\tau \cdot F_{\tau}\right)^{-1}
$$

Consequently, the aiming radar under consideration can track from 5 (at a distance of $24 \mathrm{~km}$ ) to 7 (at a distance of $2 \mathrm{~km}$ ) targets in the specified scan sector.

The obtained results confirm the fundamental possibility of increasing the throughput capacity of an existing radar equipment by implementing the new approach to the formation of the measuring channel of the MPAR in tracking mode.

\section{Conclusions}

It should be noted that both the provided quantitative evaluation of the radar signals parameters and, accordingly, the number of targets being tracked are not final, since the selection of these parameters in each specific case is performed considering all contributing factors [4]. At the same time, the practical implementation of such a choice is quite feasible due to the use of the so-called programmable signal processor [1], which allows us to generate the required types of probing signals by using various subprograms of their processing.

\section{References}

1. Методика розрахунку ймовірності виконання вогневої задачі зенітним артилерійським комплексом ближньої дії при введенні в його склад багаточастотної трикоординатної РЛС/В.В. Воїнов, Г.В. Срмаков, І.Г. Леонов, С.М. Телюков // Системи озброєння і військова техніка. - 2010. - № 3(23). - С. 25-29.

2. Смирнов О Л. Эффективность нелинейной схемы компромиссов при управлении режимом сопровождения многофункциональной РЛС / О.Л. Смирнов, О.Н. Ставицкий, С.О. Рябоконь // Наука і техніка Повітряних Сил Збройних Сил України. - 2009. - № 2(2). - С. 59-61.

3. Мегельбей В.В. Принципи побудови адаптивного алгоритму управління роботою багатофункціональної РЛС при суміщенні режимів виявлення (допошуку), супроводження повітряних цілей та наведення ракет / В.В. Мегельбей // Системи озброєння і військова техніка. - 2015. - № 4(44). - С. 28-31.

4. Shevchenko A. Multi-Frequency Signals Forming for MIMO Radars with Fast Electronic Scanning / A. Shevchenko, I. Trofimov, A. Dudush // Telecommunications and Radio Engineering, USA. - 2015. - No. 5(74). - P. 409-422.

5. Kadri B. Phase-Only Planar Antenna Array Synthesis with Fuzzy Genetic Algorithms / B. Kadri, M. Boussahla, F.T. Bendimerad // IJCSI International Journal of Computer Science Issues. - January 2010. - Vol. 7, Issue 1, No. 2. - ISSN (Online): 1694-0784 ISSN (Print): 1694-0814. P. 72-77.

6. Цифровая обработка сигналов в многофункциональных радиолокаторах. Методы. Алгоритмы. Аппаратура / Н.И. Авдеев, М.С. Баранова, Д.Ю. Бобров и др.; под ред. Г.В. Зайцева. - М.: Радиотехника, 2015. - 376 с.

7. Изделие 9Ф638. Техническое описание. Ч. 7. Система сопровождения цели и ракет: БА2 076202 ТО6. - М.: Военное издательство, 1990. - 84 с.

8. Вишнякова Л.В. Система автоматизированного формирования облика зенитных ракетных комплексов / Л.В. Вишнякова, В.И. Кухтенко // Техническая кибернетика. - 1993. - № 6. - С. 137-185.

9. Трухачев А.А. Радиолокационные сигналы и их применения / А.А. Трухачев. - М.: Воениздат, 2005. -320 c.

10. Симаранов С.Ю. Адаптивное управление параметрами режима сопровождения в многоканальных информационных системах / С.Ю. Симаранов // Техническая кибернетика. - 1989. - № 2. - С. 128-131.

11. Смирнов О.Л. Адаптивное управление параметрами режима сопровождения многофункциональной РЛС / О.Л. Смирнов, О.Н. Ставицкий, А.А. Наконечный // Наука і техніка Повітряних Сил Збройних Сил України. - 2017. № 1(26). - C. 71-77. https://doi.org/10.30748/nitps.2017.26.15.

12. Бабкин Ю.М. Синтез многофункционального радиолокатора / Ю.М. Бабкин, В.А. Балагуровский. - М.: МЭИ, 2006. $-108 \mathrm{c}$.

Received by Editorial Board 19.08.2020 Signed for Printing 15.09.2020

\section{Відомості про авторів:}

\section{Смірнов Олег Леонідович}

кандидат технічних наук доцент

доцент кафедри Харківського національного

університету Повітряних Сил ім. І. Кожедуба,

Харків, Україна

https://orcid.org/0000-0002-6972-0992

\section{Information about the authors:}

\author{
Oleg Smirnov \\ Candidate of Technical Sciences Associate Professor \\ Senior Lecturer of Ivan Kozhedub \\ Kharkiv National Air Force University, \\ Kharkiv, Ukraine \\ https://orcid.org/0000-0002-6972-0992
}


Наконечний Олександр Анатолійович кандидат технічних наук доцент доцент кафедри Харківського національного університету Повітряних Сил ім. І. Кожедуба, Харків, Україна https://orcid.org/0000-0002-9659-9681

\section{Бологов Андрій Вікторович}

викладач кафедри

Харківського національного університету

Повітряних Сил ім. І. Кожедуба,

Харків, Україна

https://orcid.org/0000-0002-2243-9001

\section{Oleksandr Nakonechnyi}

Candidate of Technical Sciences Associate Professor

Senior Lecturer of Ivan Kozhedub

Kharkiv National Air Force University,

Kharkiv, Ukraine

https://orcid.org/0000-0002-9659-9681

\author{
Andriy Bologov \\ Instructor of Ivan Kozhedub \\ Kharkiv National \\ Air Force University, \\ Kharkiv, Ukraine \\ https://orcid.org/0000-0002-2243-9001
}

\section{ФОРМУВАННЯ КАНАЛУ ВИМІРЮВАНЬ БАГАТОФУНКЦІОНАЛЬНОЇ РЛС В РЕЖИМІ СУПРОВОДЖЕННЯ}

О.Л. Смірнов, О.А. Наконечний, А.В. Бологов

Розглянуто принцип формування каналу вимірювань багатофункиіональної РЛС в режимі супроводження на прикладі одного з радіолокаційних засобів ЗРК малої дальності з метою підвищення пропускної здатності РЛС зокрема, у режимі супроводження малорозмірних повітряних иілей. Проаналізовано існуючу процедуру формування зондувальних сигналів в динаміці, по етапам наближення до зенітної ракетної системи. Виділено основні особливості процедури, до яких можуть бути внесені зміни з метою оптимізації ї̈ енергетичних та часових показників. Викладена оиінка можливості підвищення пропускної здатності РЛС за рахунок відмови від супроводження иілі з постійними значеннями тривалості такту вимірювання та частоти його повторення. Запропоновано новий підхід до формування каналу, заснований на врахуванні зміни рівнів шумів в самому каналі вимірювань $і$ в моделі динаміки супроводжуваної иілі, адаптивному до ї̈ переміщення в просторі. Запропонована нова (модифікована) проиедура формування зондувальних сигналів, адаптована до нового каналу вимірювань РЛС. Проведено розрахунок кількості одночасно супроводжуваних иілей за умови застосування запропонованого принципу формування каналу. Отримані результати підтверджують принципову можливість підвищення пропускної здатності існуючого зразка радіолокачійного озброєння за рахунок застосування нового підходу до формування каналу вимірювань РЛС в режсимі супроводу. Відзначено, щзо наведені кількісні оиінки параметрів радіолокаційних сигналів $i$, відповідно, числа супроводжуваних иілей не є остаточними, тому що вибір ицих параметрів в кожному конкретному випадку проводиться на підставі детального обліку всіх супутніх факторів. Зроблено висновок про доиільність застосування даного методу у існуючих комплексах ППО, модернізація яких наразі здійснюється.

Ключові слова: багатофункиіональна РЛС, режим супроводження, канал вимірювань, пропускна здатність.

\section{ФОРМИРОВАНИЕ КАНАЛА ИЗМЕРЕНИЙ МНОГОФУНКЦИОНАЛЬНОЙ РЛС В РЕЖИМЕ СОПРОВОЖДЕНИЯ}

\section{О.Л. Смирнов, А.А. Наконечный, А.В. Бологов}

Рассмотрен принции формирования канала измерений многофункциональной РЛС в режиме сопровождения на примере одного из радиолокачионных средств ЗРК малой дальности. Предложен новый подход к формированию канала, основанный на учете изменения уровней шумов в самом канале измерений и модели динамики сопровождаемой цели, адаптивном кее перемещению в пространстве. Проведен расчет количества одновременно сопровождаемых иелей при условии применения предложенного принципа формирования канала. Подтверждена эффективность полученных решений. Сделан вывод о целесообразности применения данного метода в существующих комплексах ПВО, модернизация которых сейчас осуществляется.

Ключевые слова: многофункииональная РЛС, режим сопровождения, канал измерений, пропускная способность. 